\title{
A study on Ground Water Quality Used for Irrigation in Prakasam District of A.P., India using Geographical Information Systems
}

\author{
Ch. Maruti Devi, Dr. Kiran Yarrakula and Dr.T. Usha Madhuri
}

\begin{abstract}
The ground water samples collected from different mandals of prakasam district are analyzed in the laboratory for electrical conductivity (EC), $\mathrm{pH}$, cations $\left(\mathrm{Na}^{+}, \mathrm{K}^{+}, \mathrm{Ca}^{2+}\right.$ and $\left.\mathrm{Mg}^{2+}\right)$ and anions $\left(\mathrm{CO}_{3}^{2-}, \mathrm{HCO}_{3}{ }^{-}, \mathrm{Cl}\right.$ and $\left.\mathrm{SO}_{4}{ }^{-}\right)$. The water samples are categorized as per criterion developed by Central Soil Salinity Research Institute, India. It has been found that, out of 55 Mandals, 35 Mandals have been found to be good in quality for irrigation at the district. Whereas 13 Mandals were found Saline (Marginally Saline (B1)-6, Saline (B2) - 2, High SAR Saline (B3) -5) and 7 Mandals are found as in Alkali category (Marginally Alkali (C1)-NIL, Alkali (C2)-3, Highly Alkali (C3)- 4). In general, these waters were of Ca-Na-Mg type with the dominance of $\mathrm{HCO}_{3}$ and $\mathrm{CO}_{3}$ in case of good quality waters. The poor water quality belonged to categories of $\mathrm{B1}, \mathrm{B2}, \mathrm{B3}, \mathrm{Cl}, \mathrm{C2}$ and $C 3$, which are either having accumulation of salts (high $E C)$ or high Sodium adsorption ratio (SAR) or Residual Sodium Carbonate (RSC). Thematic maps are generated on the basis of different categories of ground water samples using ARC GIS 9.3 software depicting the places of saline and alkali water in the district.
\end{abstract}

Keywords--- Anions, Cations, CSSRI, EC, Image Processing, pH, RSC, SAR, Water Quality

\section{INTRODUCTION}

$\mathrm{G}$ ROUND water is a good source of fresh water available on the Earth. Most of the water is being used for growing crops and vegetables. Due to urbanization and industrialization, the ground water is being polluted in several major cities of the country [16]. The ground water resources are often over exploited to meet the increasing demand by the people. Sometimes ground water contains various minerals and salts in solution at elevated concentrations posing danger to the human conception or utility. The well or tube well waters are expected to contain more dissolved salts of the

Ch. Maruti Devi, Assistant Professor, Civil Engineering Department, Bapatla Engineering College, Bapatla, India. E-mail: chennamsetty1970@gmail.com

Dr. Kiran Yarrakula, Associate Professor, Civil Engineering Department, Bapatla Engineering College, Bapatla, India. E-mail: kiranyadavphysik@gmail.com

Dr.T. Usha Madhuri, Assistant Professor, Civil Engineering Department, Andhra University College of Engineering, Visakhapatnam, India. E-mail: tanukusrinivas@hotmail.com

DOI: 10.9756/BIJIEMS.10038 sodium, calcium and magnesium and their use in irrigation results in the increase of the salinity of the soil and thereby the loss of fertility [3]. Further, the presence of accumulated amounts of high concentration of carbonate and bicarbonates of alkali or alkaline earth metals, turns to be responsible for the dispersion of soil particles that ultimately reduces porosity of the soil and thereby the loss of fertility $[12,13]$. The endeavor of the present study is to assess the ground water suitability for irrigation pertains to 55 Mandals of Prakasham Distinct Andhra Pradesh, India [6]. Figure 1 depicts the location map of Prakasam District, India.

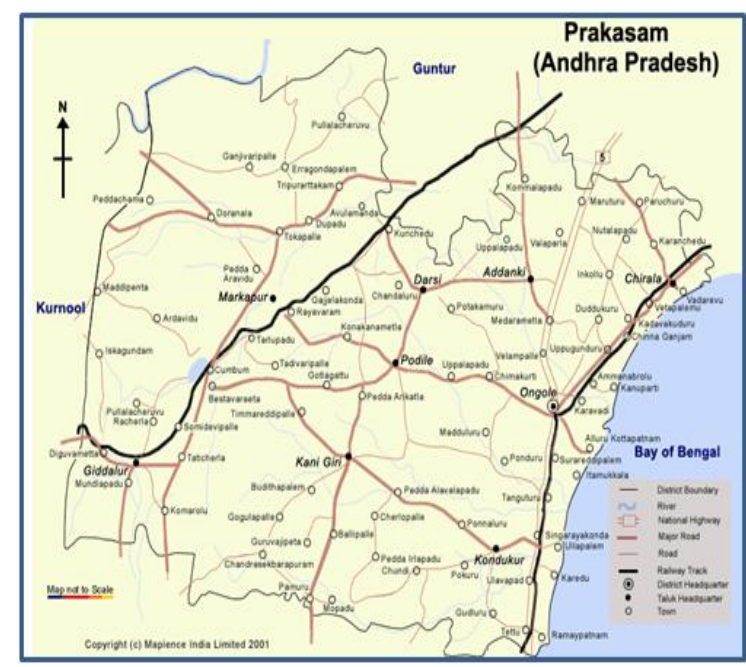

Figure 1: Location Map of the Study Area - Prakasam District

\section{MATERIALS AND METHODS}

Prakasam District is situated in tropical region between $14057^{\prime} 00^{\prime \prime}$ to $16017^{\prime} 00^{\prime \prime}$ Northern Latitude and $78043^{\prime} 00^{\prime \prime}$ to 80025 '00" Eastern Longitude. The agriculture activity in the district is deplorable owing to gambling of monsoons and unreliable rainfall and much dependence on tanks and wells for irrigation. The district receives rains from South-west and north east monsoons during the month of June to December. The average rainfall is $616 \mathrm{~mm}$. Red loamy, Black cotton and Sandy Loams are the predominant soils in the district [7]. The central portion of the district contains large tracts of low shrubs and jungle diversified with rocky hills and stony plains which is a peculiar feature of the District. The samples were collected from open dug or tube wells. The open wells vary in depth from 5 to $25 \mathrm{~m}$, whereas the tube wells pump out water from $25-100 \mathrm{~m}$ depth [4]. For the present study, 340 ground water samples were collected from 55 selected mandal stations 
of Prakasam District. The geographical position of sampling well station was recorded with the help of Global Positioning System (GPS). The water sample of about one liter from each well or tube well was collected in clean acid washed polythene bottles during April, June and October. The samples from open well had been collected using "sample thief" at bottom, middle and upper portions of the well and then, they were mixed to get homogenous solution as detailed in the literature $[9,11]$.

The samples collected were analyzed for $\mathrm{pH}$ using $\mathrm{pH}$ meter (systronic make) Electrical conductivity (EC) using Conductivity meter (Systronic make). The concentrations of $\mathrm{Na}+, \mathrm{K}+, \mathrm{Ca} 2+, \mathrm{Mg} 2+, \mathrm{CO} 32-, \mathrm{HCO} 3-, \mathrm{Cl}-$ and $\mathrm{SO} 4-$ were obtained through the standard laboratory methods available in Literature [1, 2]. Sodium Adsorption ratio (SAR) [5] and Residual Sodium Carbonate (RSC) [8] were calculated by the following equations 1 and 2 .

$$
\begin{aligned}
& \operatorname{SAR}\left(m \mathrm{~mol}^{-1}\right)^{1 / 2}=\frac{N a^{+}}{\sqrt{\frac{\left(\mathrm{Ca}^{++}+M g^{++}\right)}{2}}} \\
& \operatorname{RSC}\left(\mathrm{meL}^{-1}\right)=\mathrm{CO}_{3}^{-}+\mathrm{HCO}_{3}^{-}-\mathrm{Ca}^{++}+\mathrm{Mg}^{++}
\end{aligned}
$$

(All values of cations and anions are in meL-1)

The collected ground water samples were classified representing salinity and alkalinity as per the criteria suggested by the Central Soil Salinity Research Institute (CSSRI), India [15] (Table 1). The spatial distribution maps were generated on the basis of different categories of ground water samples, using ARC GIS 9.3 software depicting the places of Saline and Alkali waters in the district.

Table1: Categorization of Ground Waters on the Basis of EC,

\begin{tabular}{|c|c|c|c|}
\hline Water Quality & $\begin{array}{c}\text { Electrical } \\
\text { Conductivity } \\
\left(\mathrm{dSm}^{-1}\right)\end{array}$ & $\begin{array}{c}\mathrm{SAR}\left(\mathrm{mmoL}^{-}\right. \\
\left.{ }^{1}\right) 1 / 2\end{array}$ & $\begin{array}{c}\mathrm{RSC}(\mathrm{me} \\
\left.\mathrm{L}^{-1}\right)\end{array}$ \\
\hline A. Good & $<2$ & $<10$ & $<2.5$ \\
\hline $\begin{array}{c}\text { B. Saline waters } \\
\text { B 1. Marginally saline }\end{array}$ & $2-4$ & $<10$ & $<2.5$ \\
\hline
\end{tabular}
SAR, and RSC, Standards Suggested by CSSRI, India

\begin{tabular}{|c|c|c|c|}
\hline B 2. Saline & $>4$ & $<10$ & $<2.5$ \\
B 3.High SAR Saline & $>4$ & $>10$ & $<2.5$ \\
\hline C. Alkali waters & & & \\
C 1. Marginally alkali & $<4$ & $<10$ & $2.5-4.0$ \\
C 2. Alkali & $<4$ & $<10$ & $>4.0$ \\
C 3. Highly alkali & Variable & $>10$ & $>4.0$ \\
\hline
\end{tabular}

\section{RESULTS AND DISCUSSION}

The suitability of well or tube well waters for irrigation depends upon the mineral constituents present in the water. The important factors that influence the irrigation water quality are salt concentration as represented by EC, SAR and RSC [8]. Excessive amount of salt in general and sodium in particular affect the soil permeability, soil structure and create toxic condition for plants. Sodium of the irrigation water was generally taken up by the clays in return of Calcium and Magnesium due to ion exchange. This happened in case of C1 and $\mathrm{C} 2$ irrigation water categories. It leads to the development of Alkali soil, which had un-favorable structure and restricts aeration. To quantify this effect an empirical parameter termed as SAR was used [10]. The analytical and calculated values were given in Table 2 . The results of study revealed that EC of the samples varied from 0.41 to $7.86 \mathrm{dsm}-1$, SAR from 0.38 to 35.19 (mmolesL-1), $\mathrm{pH}$ from 7.90 to 9.05 and RSC from -32.16 to 7.97 meL-1. The salient features of ground water samples of Prakasam district is shown in Table 2. The dominant cat ion present in ground water samples of this region was $\mathrm{Ca}++$ and in some cases $\mathrm{Na}+$ was the dominant one. The dominant anions were $\mathrm{HCO} 3-, \mathrm{Cl}-$ and SO4-2. Most of the samples were of Ca-Na-Mg type with the dominance of $\mathrm{Cl}$-followed by bicarbonate and carbonate in case of good quality water.

Out of fifty five mandal stations, thirty five mandals were found to be good in quality for the purpose of irrigation. Under the category of Saline waters, six stations were come under Marginally Saline (B1) category. Two stations were in Saline (B2) category and five stations were in High SAR Saline (B3) category. While classify the water with respect to Alkali category, no station was identified under Marginally alkali (C1) category and three stations were in Alkali (C2) category. Four stations were observed in Highly Alkali (C3) category.

Table 2: Salient features of Ground Water samples of Prakasam District

\begin{tabular}{|c|l|c|c|c|c|c|c|}
\hline Sl.No & $\begin{array}{l}\text { Object } \\
\text { Created } \\
\text { in GIS } \\
\text { map }\end{array}$ & $\begin{array}{c}\text { Name of the } \\
\text { Mandal Station }\end{array}$ & pH & $\begin{array}{l}\text { SAR } \\
(\mathrm{mmoL}- \\
1) 1 / 2\end{array}$ & $\begin{array}{c}\text { RSC } \\
\text { (me } \\
\text { L-1) }\end{array}$ & $\begin{array}{c}\text { EC } \\
(\mathrm{dSm}- \\
1)\end{array}$ & Classification \\
\hline 1 & 1 & Giddaluru & 8.46 & 3.65 & -10.6 & 2.27 & B1 \\
\hline 2 & 3 & Komarolu & 8.56 & 7.00 & -5.58 & 2.10 & B1 \\
\hline 3 & 4 & Bestavaripeta & 8.61 & 3.95 & -2.16 & 2.00 & B1 \\
\hline 4 & 5 & Racherla & 8.48 & 1.29 & -5.61 & 1.01 & A \\
\hline 5 & 6 & Veligendla & 8.66 & 1.35 & -1.98 & 0.92 & A \\
\hline 6 & 7 & C.S.puram & 8.51 & & & & A \\
\hline
\end{tabular}




\begin{tabular}{|c|c|c|c|c|c|c|c|}
\hline 7 & 8 & Pamuru & 8.92 & 12.92 & 6.64 & 0.41 & $\mathrm{C} 3$ \\
\hline 8 & 9 & Hanumantunipadu & 8.93 & 7.94 & 4.40 & 1.42 & $\mathrm{C} 2$ \\
\hline 9 & 10 & Cumbum & 8.43 & 4.41 & 0.17 & 0.72 & $\mathrm{~A}$ \\
\hline 10 & 11 & Tarlapadu & 8.64 & 1.56 & -1.17 & 0.96 & $\mathrm{~A}$ \\
\hline 11 & 12 & K.K.Mitta & 8.42 & 4.08 & -6.04 & 1.10 & A \\
\hline 12 & 13 & Kanigiri & 8.40 & 2.57 & -7.97 & 1.57 & A \\
\hline 13 & 14 & P.C.Palli & 8.71 & 13.37 & 1.16 & 4.41 & B3 \\
\hline 14 & 15 & Lingasamudram & 9.66 & 1.09 & -2.63 & 0.97 & A \\
\hline 15 & 16 & V.V._Palem & 8.20 & 5.24 & -3.00 & 0.82 & A \\
\hline 16 & 17 & Ponnaluru & 8.20 & 2.77 & -0.18 & 0.78 & A \\
\hline 17 & 18 & Jarugumalli & 8.40 & 7.98 & -2.17 & 1.97 & $\mathrm{~A}$ \\
\hline 18 & 19 & Marripudi & 8.71 & 3.47 & -1.43 & 1.63 & A \\
\hline 19 & 20 & Kondepi & 8.58 & 2.78 & -0.81 & 0.90 & $\mathrm{~A}$ \\
\hline 20 & 21 & Podili & 9.04 & 10.75 & -2.43 & 4.63 & B3 \\
\hline 21 & 22 & Darsi & 8.51 & 0.73 & 4.22 & 0.67 & $\mathrm{C} 2$ \\
\hline 22 & 23 & Kuruchedu & 8.00 & 8.77 & $\begin{array}{c}- \\
32.16\end{array}$ & 7.45 & $\mathrm{~B} 2$ \\
\hline 23 & 24 & Donakonda & 8.59 & 2.59 & -1.57 & 0.73 & A \\
\hline 24 & 25 & Markapuram & 8.92 & 12.81 & 4.00 & 1.64 & $\mathrm{C} 3$ \\
\hline 25 & 26 & Pullalacheruvu & 8.36 & 1.22 & -1.16 & 0.41 & $\mathrm{~A}$ \\
\hline 26 & 28 & Yerragondapalem & 8.48 & 2.14 & -2.58 & 0.64 & $\mathrm{~A}$ \\
\hline 27 & 29 & Dornala & 8.27 & 10.00 & -9.22 & 3.94 & $\mathrm{~B} 1$ \\
\hline 28 & 30 & Peddaraveedu & 8.51 & 2.97 & 0.17 & 0.82 & A \\
\hline 29 & 31 & Gudluru & 8.49 & 0.66 & -7.78 & 1.09 & A \\
\hline 30 & 32 & Kandukuru & 8.78 & 8.37 & 2.42 & 1.67 & A \\
\hline 31 & 33 & Ulavapadu & 8.34 & 8.28 & -1.03 & 0.68 & A \\
\hline 32 & 34 & singarayakonda & 8.72 & 7.58 & -1.96 & 1.72 & A \\
\hline 33 & 35 & Tanguturu & 8.65 & 1.94 & 0.84 & 0.55 & $\mathrm{~A}$ \\
\hline 34 & 36 & Kothapatnam & 8.28 & 11.60 & -9.77 & 6.13 & B3 \\
\hline 35 & 37 & S.N.padu & 8.69 & 5.77 & 0.03 & 1.20 & A \\
\hline 36 & 38 & Cheemakurthy & 8.27 & 0.51 & -5.56 & 0.72 & A \\
\hline
\end{tabular}




\begin{tabular}{|c|c|c|c|c|c|c|c|}
\hline 37 & 39 & Talluru & 8.83 & 1.72 & -2.61 & 0.79 & A \\
\hline 38 & 40 & Mundlamuru & 8.48 & 0.38 & -4.17 & 0.82 & A \\
\hline 39 & 41 & Addanki & 8.88 & 4.74 & 1.84 & 0.90 & $\mathrm{~A}$ \\
\hline 40 & 42 & Balikurava & 8.76 & 4.89 & -4.64 & 2.09 & B1 \\
\hline 41 & 43 & S.Manguluru & 8.63 & 8.85 & 7.97 & 2.22 & $\mathrm{C} 2$ \\
\hline 42 & 44 & Marturu & 8.90 & 1.63 & -1.61 & 0.88 & A \\
\hline 43 & 45 & J. Panguluru & 8.40 & 7.98 & -2.17 & 1.97 & A \\
\hline 44 & 46 & Inkollu & 8.01 & 2.70 & -1.74 & 0.89 & A \\
\hline 45 & 47 & Karamchedu & 7.90 & 2.80 & -1.52 & 0.96 & A \\
\hline 46 & 48 & Vetapalem & 8.80 & 0.66 & -1.77 & 6.16 & B2 \\
\hline 47 & 49 & Chinaganjam & 8.56 & 1.77 & -1.60 & 0.75 & $\mathrm{~A}$ \\
\hline 48 & 50 & Naguluppalapadu & 8.28 & 11.00 & -2.80 & 6.13 & B3 \\
\hline 49 & 51 & Maddipadu & 8.69 & 35.19 & -3.19 & 9.25 & B3 \\
\hline 50 & 52 & Chirala & 8.01 & 2.70 & -1.74 & 0.89 & A \\
\hline 51 & 53 & Parchuru & 7.90 & 2.80 & -1.52 & 0.96 & A \\
\hline 52 & 54 & Yeddanapudi & 8.94 & 18.80 & 7.38 & 7.86 & $\mathrm{C} 3$ \\
\hline 53 & 55 & Tripuranthakam & 8.79 & 2.08 & -1.81 & 0.99 & $\mathrm{~A}$ \\
\hline 54 & 56 & Arthaveedu & 8.49 & 4.29 & -8.78 & 2.55 & $\mathrm{~B} 1$ \\
\hline 55 & 57 & Ongole (West) & 9.05 & 17.81 & 6.71 & 4.61 & $\mathrm{C} 3$ \\
\hline
\end{tabular}

\section{SPATIAL DISTRIBUTION MAPS FOR IRRIGATION SUITABILITY}

The irrigation suitability was prepared for Prakasam District based on SAR, EC, and RSC values and mapping of SAR, EC, and RSC were prepared in GIS platform [14]. The spatial distribution pattern of SAR, EC, and RSC were shown in Figures 2, 3 and 4 respectively. It indicates that most of the waters were in good of quality for irrigation. A large area of thirteen mandal waters showed Saline ground water area. Only small patches of Mandals showed the area of Alkali water. Marginally Alkaline category (C1) was totally absent in the district. Hanumantunipadu, Darsi and S.Manguluru areas showed the area of alkali water (C2). Pamuru, Markapur,Yeddanapudi and Ongole areas showed highly alkali (C3) category in Prakasam district.

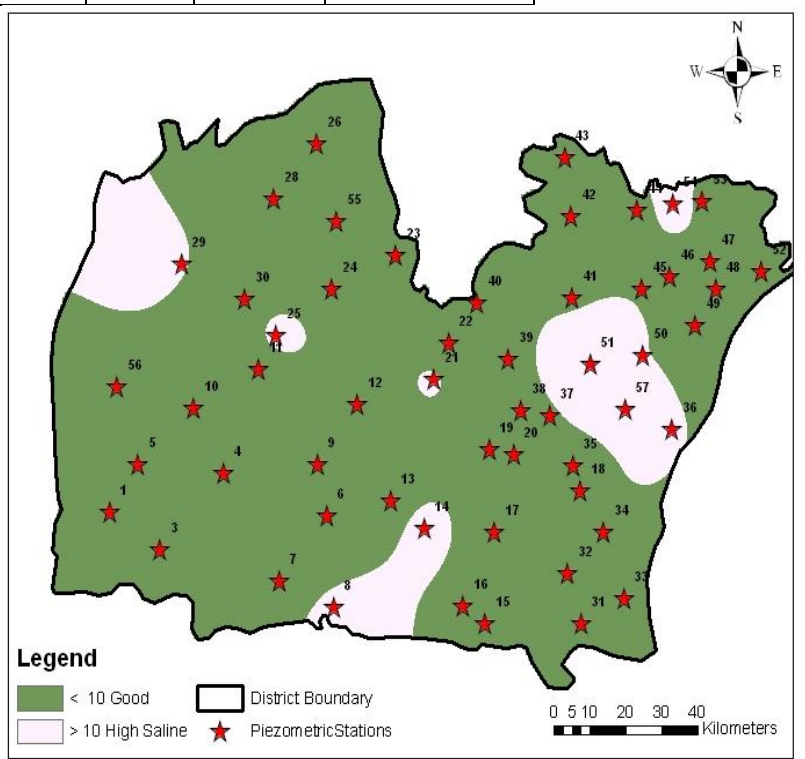

Figure 2: Spatial Distribution of SAR mapping 


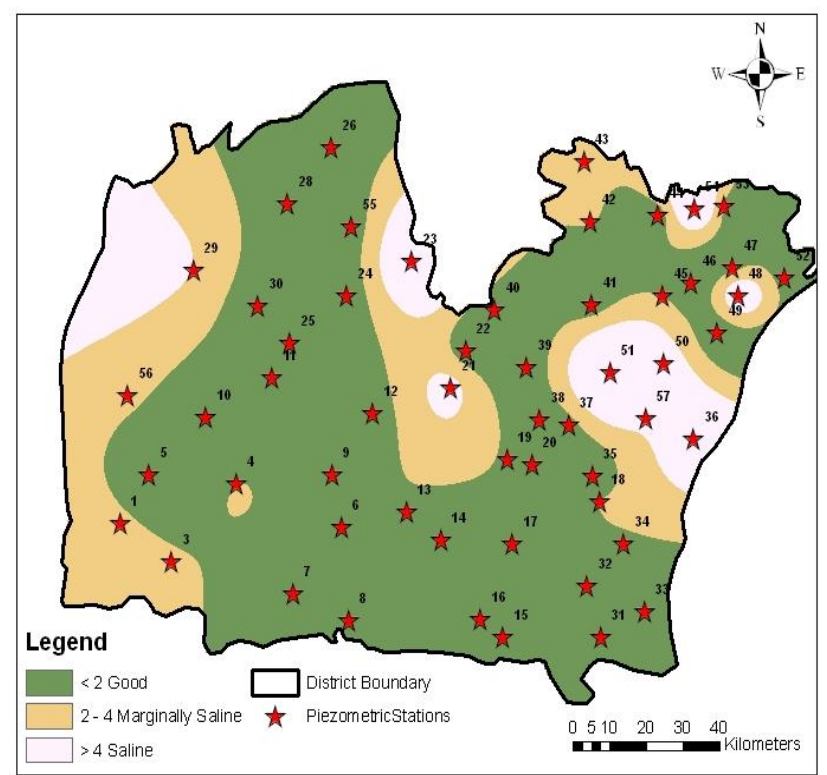

Figure 3: Spatial Distribution of Electrical Conductivity (EC) Mapping

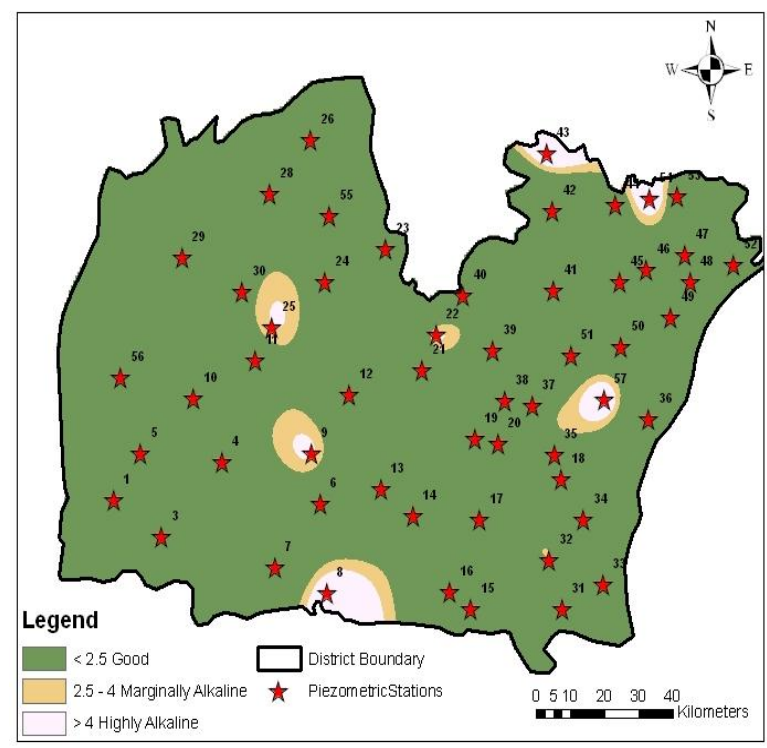

Figure 4: Spatial Distribution of RSC Mapping

\section{CONCLUSIONS}

The study reveals that, thirty five stations namely Racherla, Veligendla, C.S. Puram, Cumbum, Tarlapadu, K.K.Mitta, Kanigiri, Lingasamudram, V.V.Palem, Ponnaluru, Jarugumalli, Marripudi, Kondepi, Donakonda,Pullalacheruvu, Yerragondapalem, Peddaraveedu, Gudluru, Kandukuru, Ulavapadu, Singarayakonda, Tanguturu, S.N.Padu, Cheemakurthy, Talluru, Mundlamuru, Addanki, Marturu, J.Panguluru, Inkollu, Karamchedu, Chinaganjam, Chirala, Parchuru, Tripuranthakam mandal stations were found as good in quality for irrigation suitability comes as category A. Giddaluru, Komarolu, Bestavaripeta, Dornala, Ballikurva and Arthaveedu mandal stations were marginally under saline zone (B1) and two stations namely Kuruchedu and Vetapalem stations were identified as Saline (B2) category. The stations P.C.Palli, Podili, Kothapatnam, Naguluppalapadu, Maddipadu were come under High SAR Saline (B3) category. In Alkali zone, No station area was come under Marginally Alkali (C1) category. Three mandal stations namely Hanumantunipadu, Darsi and S.Manguluru were come under the category of Alkali (C2). The four stations namely Pamuru, Markapuram, Yeddanapudi and Ongole (West) were come beneath Highly Alkali (C3) category.

\section{REFERENCES}

[1] APHA, Standard methods for the examination of water and wastewater American Public Health Association, New York, U.S.A, 1985.

[2] BIS10500, Bureau of Indian standards for drinking water, 1991.

[3] Burjia.J.S., and Romani, S., Groundwater development - Present scenario and future nees: Indian journal Pub. Adm. XLIX (3), 301307, 2003.

[4] Kotaiah. B and Kumaraswamy, N., Environmental Engineering Laboraratory Manual Charotar Publishing House, Gujarat, 1994.

[5] Chopra, S.L., and Kanwar,J.s., Analytical Agricultural Chemistry, Kalyani Pub., Pp.292 2010.

[6] Gupta Sanjay Kumar Achilles' and Seth Gita, Seasonal variation of some metals in surface water of Sanganer Are, Jaipur, Rajasthan, Indian Journal of Environmental Science., Vol. 10(1),75-77, 2006.

[7] Hand Book of Prakasam District, Statistical Department, 2011.

[8] Kulasekaran. A and ChettiyaGounder. K, Water quality problems in Tamil Nadu, TWAD Board News Letter, Vol. I (2), 11-18, 1998.

[9] Manivasakam,N.,Physicochemical Examination of water, Sewage and Industrial Effluents, Pragati Prakashan, Pp.234, 2002.

[10] Rahul Mohan, Singh A.K., Tripathi J.K. and Chowdhary G.C., Hydrochemistry and quality assessment of groundwater in Naini Industrial area, Allahabad district, Uttar Pradesh, J. Geological Soc. India. Vol. Pp 55.77-89, 2000.

[11] Singh, Ajith Pratap and Ghosh. S.K, Assessment of Water Quality Index for Yamuna Pollution Research., Vol. 18(4). Pp 435-439, 1999.

[12] Srivastsava R.K. and Seema Srivatsava, Assessment of groundwater quality of river GairatJabalpur, Indian Journal of Environmental Protection, Vol. 23(3), Pp 282-285, 2003.

[13] Trivedy.A.K.and Goel,P.K. Chemical and Biological Methods for pollution Studies. Environmental Publications, Karad, 1993.

[14] Usha Madhuri. T and T. Srinivas, A study on ground water quality in commercial areas of Visakhapatnam, Pollution Research, Vol. 23 (3):565-568, 2004

[15] Warthate.S.R.,Yenkie, M.K.N., Chaudhari,M.D. and Pokate, W.K., Imapact of mining activities on water and soil,J.Environ.Sci.and Engg. Vol. 48(2), Pp81-90 (2010)

[16] Khandkar. U.R, K.S. Bangar, S.C.Tiwari, Quality of Ground Water used for Irrigation in Ujjain District of Madhya Pradesh, India, Journal of Environmental science.and Engineering. Vol.50, No.3, Pp 179-186, July, 2008. 